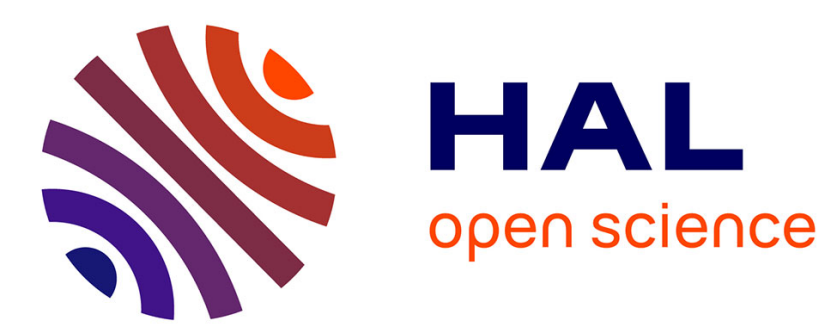

\title{
Treatment performances of French constructed wetlands: Results from a database collected over the last 30 years
}

\author{
A. Morvannou, N. Forquet, S. Michel, S. Troesch, Pascal Molle
}

\section{To cite this version:}

A. Morvannou, N. Forquet, S. Michel, S. Troesch, Pascal Molle. Treatment performances of French constructed wetlands: Results from a database collected over the last 30 years. Water Science and Technology, 2015, 71 (9), pp.1333-1339. 10.2166/wst.2015.089 . hal-01243564

\author{
HAL Id: hal-01243564 \\ https://hal.science/hal-01243564
}

Submitted on 15 Dec 2015

HAL is a multi-disciplinary open access archive for the deposit and dissemination of scientific research documents, whether they are published or not. The documents may come from teaching and research institutions in France or abroad, or from public or private research centers.
L'archive ouverte pluridisciplinaire HAL, est destinée au dépôt et à la diffusion de documents scientifiques de niveau recherche, publiés ou non, émanant des établissements d'enseignement et de recherche français ou étrangers, des laboratoires publics ou privés. 


\title{
Treatment performances of French constructed wetlands
}

\section{Results from a database collected over the last 30 years}

\author{
$\underline{\text { A. Morvannou }}^{*}, * *$, N. Forquet*, S. Michel*, S. Troesch** and P. Molle* \\ * Irstea - Wastewater treatment team - Freshwater system, Ecology and Pollution Research unit, 5 rue \\ de la Doua, CS 70077, Villeurbanne Cedex, 69 626, FRANCE \\ (E-mail: ania.morvannou@irstea.fr - nicolas.forquet@irstea.fr - sylvain.michel@irstea.fr - \\ pascal.molle@irstea.fr) \\ ** Epur Nature - 12 rue Toussaint Fléchaire, Caumont-sur-Durance, 84 510, France \\ (E-mail: ania.morvannou@epurnature.fr - stephane.troesch@epurnature.fr)
}

\begin{abstract}
Approximately 3,500 constructed wetlands (CWs) provide treatment of raw wastewater in France for small communities $(<5,000$ people equivalent). Built during the past 30 years, most consist of two vertical flow constructed wetlands (VFCW) in series (stages). Many configurations exist, with systems associated with horizontal flow filters or waste stabilization ponds, vertical flow with recirculation, partially saturated systems, etc. A database analyzed 10 years earlier on the classical French system summarized the global performances data. This paper provides a similar analysis of performance data from 415 full-scale two-stage VFCWs from an improved database expanded by monitoring data available from Irstea and the French technical department. Trends presented in the first study are confirmed exhibiting high COD, TSS and TKN removal rates (87\%, 93\% and 84\%, respectively). Typical concentrations at the second stage outlet are $74 \mathrm{mgCOD} . \mathrm{L}^{-1}, 17 \mathrm{mgTSS} . \mathrm{L}^{-1}$ and $11 \mathrm{mgTKN} . \mathrm{L}^{-1}$. Pollutant removal performances are summarized in relation to the loads applied on the first treatment stage. While COD and TSS removal rates remain stable over the range of applied loads, the spreading of TKN removal rates increases as applied loads increase.
\end{abstract}

\section{Keywords}

Database, vertical flow constructed wetland, treatment performances, French system

\section{INTRODUCTION}

Constructed wetlands systems (CWs) have been proven to be effective and offer an attractive and sustainable alternative for wastewater treatment technology for small communities $(<5,000$ people equivalent, p.e.). The simplicity of operation, maintenance and the low operating costs are suited to the limited resources that small communities are able to dedicate to wastewater treatment. Moreover, CWs have a high capacity for buffering hydraulic and organic load fluctuations as well as a high resilience.

After 30 years of development of constructed wetlands treating domestic wastewater for small communities in France, about 3,500 plants are currently in operation. Most of them are composed of two-stages of vertical flow constructed wetlands (VFCWs) in series, but many configurations exist (association with horizontal flow, pond systems or conventional treatment systems, one stage of vertical flow with recirculation, partially saturated systems, etc.) (Aguilera Soriano et al., 2011; Prost-Boucle and Molle, 2012; Kim et al., 2014;). Current practice usually involves two treatment stages, with three units in parallel on the first stage and two for the second, with successive periods of feeding (3.5 days), and rest periods ( 7 days at the first stage and 3.5 at the second stage) to maintain permeability, oxygen content and to control the biomass growth (Liénard et al., 1990a, b). VFCWs are appropriate when the nitrogen forms contained in wastewater have to be nitrified. A previous database analysis was carried out 10 years ago on the classical French system (two-stages 
of VFCW in series) allowing the global performances to be observed (Molle et al., 2005). Regarding the French regulation for plants with a capacity between 200 and 2,000 p.e.(minimum COD, BOD $_{5}$ and TSS removal efficiencies of $60 \%, 60 \%$ and $50 \%$, respectively, or maximum effluent concentration of $35 \mathrm{mgBOD}_{5} \cdot \mathrm{L}^{-1}$, are allowed), this system achieves very good pollutant removal efficiencies with an overall filtration surface for both stages of $2 \mathrm{~m}^{2} \cdot \mathrm{p} \cdot \mathrm{e}^{-1}:>90 \%$ for COD, $95 \%$ for TSS and $85 \%$ for nitrification, in spite of fluctuations in organic and hydraulic loads, and 60mgCOD.L $\mathrm{m}^{-1}, 15 \mathrm{mgTSS} . \mathrm{L}^{-1}$ and $8 \mathrm{mgTKN} . \mathrm{L}^{-1}$ as average concentrations at the outlet of the system.

If we focus on the first stage of VFCW, its design is based on an acceptable organic load, often expressed as a filter surface unit per p.e. Generally, the organic designed load applied on the filter in operation is of $300 \mathrm{gCOD} \cdot \mathrm{m}^{-2} \cdot \mathrm{d}^{-1}, 150 \mathrm{gTSS} \cdot \mathrm{m}^{-2} \cdot \mathrm{d}^{-1}$, and $25-30 \mathrm{gTKN} \cdot \mathrm{m}^{-2} \cdot \mathrm{d}^{-1}$. The hydraulic load is $0.37 \mathrm{~m} \cdot \mathrm{d}^{-1}$. The originality of this stage lies mainly in the fact that it is fed with raw wastewater (and therefore the development of a sludge layer over the years) as well as it is filled with a coarse granular media. Molle et al. (2005) pointed out that with a first stage surface of $1.2 \mathrm{~m}^{2} \cdot \mathrm{p} \cdot \mathrm{e}^{-1}$ it achieves a COD and TSS removal (79\% and $86 \%$, respectively) while nitrification is incomplete (50-60\% of inlet TKN).

This study provides an assessment of the overall reliability of the French system and particularly the first stage of VFCW. It takes place in order to make a more extensive database than the one used by Molle et al. (2005). We collected and summarized information about the design and operating parameters of some two-stages of VFCW currently in operation. This paper gives an overview of the number of plants, their design and their efficiency.

\section{MATERIALS AND METHODS}

\section{Data collection}

Currently around 3,500 CW plants are in operation in France. Data collection aimed at gathering all possible information on existing CWs in France: the type of filters, the altitude of the CWs, the commissioning date, feeding and drainage systems, and also filters' characteristics (e.g. the number of filters in operation, filter dimensions, particle sizes, etc). The achieved database consisted in about $700 \mathrm{CW}$ plants with different configurations (association between VFCW and HFCW or waste stabilization pond systems, VFCW with recirculation, partially saturated systems, etc.). Among them $67 \%$ are two-stages of VFCW in series and $6 \%$ have only one-stage of VFCW. Thus, a sample of $415 \mathrm{VFCW}$ plants was selected to assess treatment performances with $24 \mathrm{~h}$-flow proportional composite samples taken from the inlet and the outlet of the CWs (carried out by the French technical department (SATESE) and Irstea). These $24 \mathrm{~h}$-flow proportional composite samples included measurements of COD, BOD, TSS, TKN, $\mathrm{NH}_{4} \mathrm{~N}, \mathrm{NO}_{2} \mathrm{~N}, \mathrm{NO}_{3} \mathrm{~N}, \mathrm{PO}_{4} \mathrm{P}, \mathrm{TP}, \mathrm{pH}$ and conductivity, when they were measured, according to APHA (2012).

In this study we focused on the classic French system: two-stages of VFCW. Once the design characteristics and the $24 \mathrm{~h}$-flow proportional composite samples related to this configuration were compiled in the database, a validation step of these composite samples from the inlet of the first stage of VFCW was performed. This approach intended to remove $24 \mathrm{~h}$-flow proportional composite samples with inconsistent results or considered as outliers. Consistency was verified by calculating the following ratios between the different inlet pollutant concentrations as $\mathrm{COD} / \mathrm{BOD}_{5}, \mathrm{TKN} / \mathrm{COD}$, $\mathrm{TP} / \mathrm{COD}, \mathrm{TSS} / \mathrm{COD}, \mathrm{BOD}_{5} / \mathrm{TKN}, \mathrm{BOD}_{5} / \mathrm{TKN}$ and $\mathrm{NH}_{4} \mathrm{~N} / \mathrm{TKN}$ and comparing them to domestic wastewater values (Table 1) defined from a previous study about domestic wastewater characteristics in French rural areas (<2,000 p.e.) (Mercoiret et al., 2010). 
Table 1.Domestic wastewater characteristics in French rural areas (Mercoiret et al., 2010)

\begin{tabular}{|c|c|c|c|c|c|c|c|c|}
\hline & & \multicolumn{6}{|c|}{$\mathrm{COD} / \mathrm{BOD}_{5} \mathrm{TKN} / \mathrm{COD} \mathrm{TP} / \mathrm{COD} \mathrm{TSS} / \mathrm{COD} \mathrm{BOD}_{5} / \mathrm{TKN}^{\mathrm{BOD}}{ }_{5} / \mathrm{TP}$} & $\mathrm{NH}_{4} \mathrm{~N} / \mathrm{TKN}$ \\
\hline \multicolumn{2}{|c|}{ Mean } & 2.62 & 0.12 & 0.02 & 0.46 & 3.88 & 28.53 & 0.74 \\
\hline \multirow{2}{*}{$\begin{array}{l}\text { Range of } \\
\text { variations }\end{array}$} & $\begin{array}{l}\text { Upper } \\
\text { bound }\end{array}$ & 3.93 & 0.18 & 0.03 & 0.79 & 6.50 & 47.01 & 0.97 \\
\hline & $\begin{array}{l}\text { Lower } \\
\text { bound }\end{array}$ & 1.83 & 0.06 & 0.01 & 0.23 & 1.90 & 12.60 & 0.50 \\
\hline \multicolumn{2}{|c|}{ Number of values } & 10,275 & 9,416 & 9,184 & 10,256 & 9,416 & 9,184 & 4,244 \\
\hline
\end{tabular}

Removal efficiencies of the whole system and of each stage were calculated in $\%$ while applied and treated loads of pollutants were expressed in terms of $\mathrm{g} \cdot \mathrm{m}^{-2} \cdot \mathrm{d}^{-1}$.

\section{RESULTS}

\section{General description of the database}

Among the information collected for the $415 \mathrm{VFCW}$ plants selected in the database we note that:

- Among the two-stage VFCW plants with available data, the average dimensions of the whole system is $2 \mathrm{~m}^{2}$.p. $\mathrm{e}^{-1}$, divided between the first stage (mean: $1.2 \mathrm{~m}^{2}$.p.e $\mathrm{e}^{-1}$; min: $0.2 \mathrm{~m}^{2} \cdot \mathrm{p} \cdot \mathrm{e}^{-}$ ${ }^{1}$; max: $3.8 \mathrm{~m}^{2}$.p.e $\mathrm{e}^{-1}$; number of values: 136 ), and the second stage (mean: $0.8 \mathrm{~m}^{2} . \mathrm{p} . \mathrm{e}^{-1}$; min: $0.1 \mathrm{~m}^{2}$.p. $\mathrm{e}^{-1} ; \max : 2.7 \mathrm{~m}^{2}$.p. $\mathrm{e}^{-1}$; number of values: 133 );

- The filtering material average depth of the first stage is $53 \mathrm{~cm}$ (SD: $14 \mathrm{~cm} ; \mathrm{N}=73$ ).

- The filtration layer of the second stage is composed with a sand and fine gravel stacked layers. The average depths are $44 \mathrm{~cm}(\mathrm{SD}: 20 \mathrm{~cm} ; \mathrm{N}=106)$ for sand and $26 \mathrm{~cm}$ (SD: $10 \mathrm{~cm}$; $\mathrm{N}=64$ ) for fine gravel.

- the average plant capacity is 469 p.e. (median 330 p.e.), and $43 \%$ of the 415 VFCW plants have a nominal capacity of less than 250 p.e. (see Figure 1, left);

- theage of the plants is spread from 2 years for the most recent VFCW plant and 31 years for the oldest (mean and median: 10 years and 9 years, respectively).55\% of the plants are between 7 to 11 years old (see Figure 1, right);

- $77 \%$ of the VFCW plants only treat domestic wastewater and $78 \%$ of the VFCW are connected to a separate sewer system;

- the feeding system is mostly gravity-type (72\% and $88 \%$ of the first and the second stage of VFCW, respectively, are fed by siphon without energy supply, among the two-stages VFCW plants for those the feeding system was indicated).
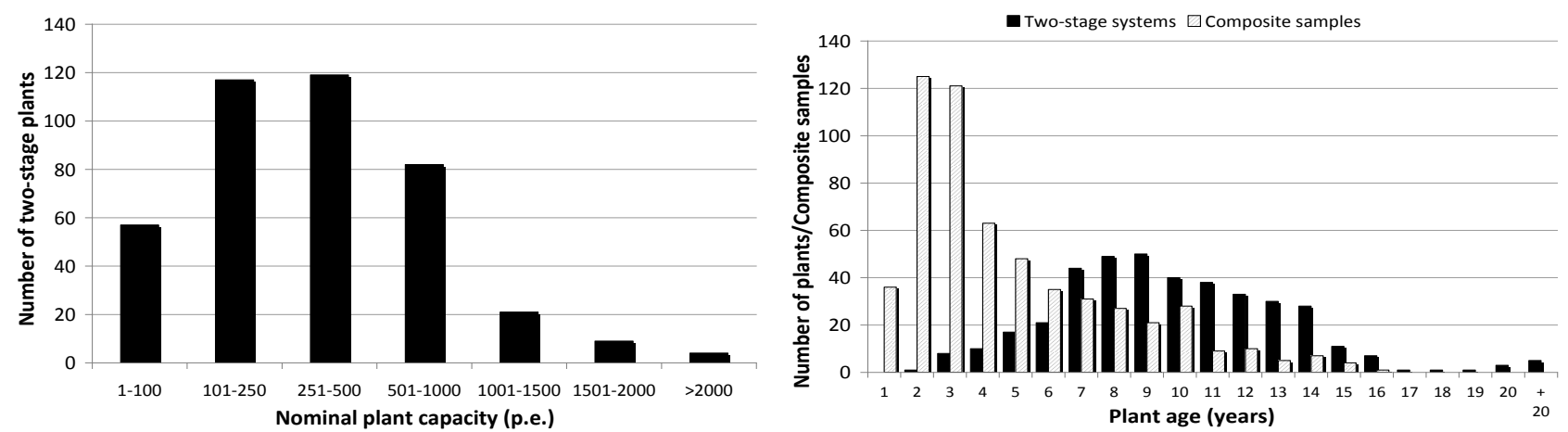

Figure 1. Distribution of the number of the two-stage systems according to the nominal plant 
capacity (left). Distribution of the number of the composite samples and the number of the two-stage systems according to the plant age (right).

Currently, the database contains 964 24h-flow proportional composite samplesfrom all available configurations listed in the database. Among these 24h-flow proportional composite samples, 535correspond to the two-stage VFCW configuration and 259 correspond to the output of the first VFCW stage.

Figure 2 presents the dispersion of $\mathrm{COD}, \mathrm{BOD}_{5}$, TSS (left) and TKN(right) concentrations measured in the raw wastewater.
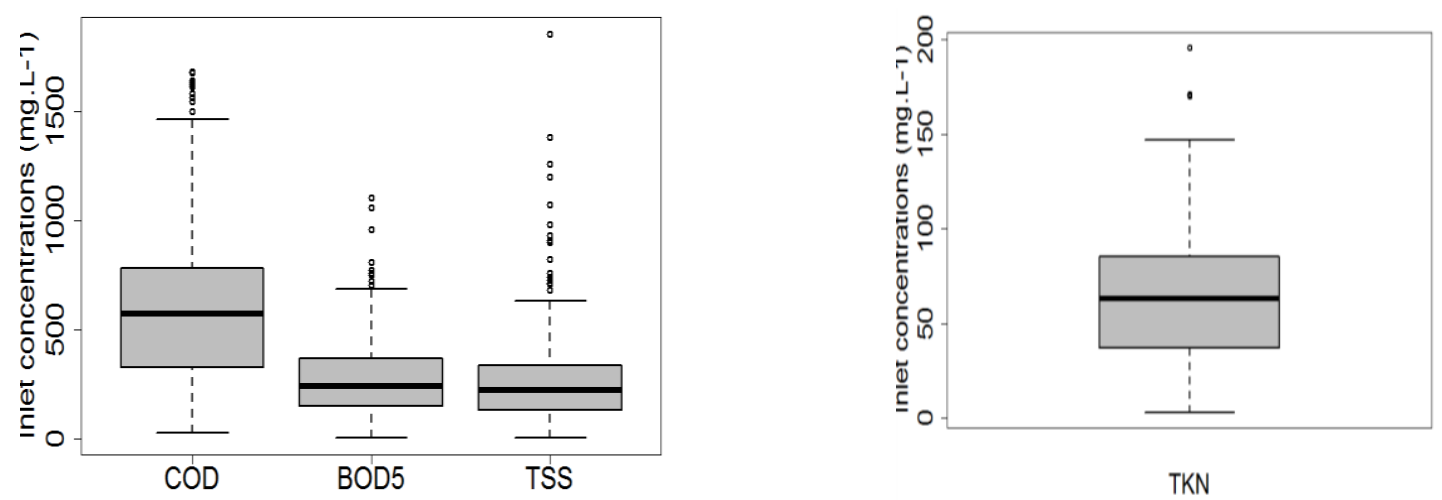

Figure 2. Raw wastewater concentrations (COD, $\mathrm{BOD}_{5}$ and TSS on the left; TKN on the right) applied on the two-stage VFCW system. $\mathrm{N}=394, \mathrm{~N}=386, \mathrm{~N}=397$ and $\mathrm{N}=325$ for $\mathrm{COD}, \mathrm{BOD}_{5}$, TSS and TKN, respectively. $\mathrm{N}$ : the number of values

Mean and median concentration values are close for all parameters (COD, BOD 5 , TSS and TKN). In this sample $90 \%$ of COD, $\mathrm{BOD}_{5}$, TSS and TKN concentrations are below 1036mg.L $\mathrm{L}^{-1}, 484 \mathrm{mg} . \mathrm{L}^{-1}$, 508mg. $\mathrm{L}^{-1}$ and $110 \mathrm{mg} . \mathrm{L}^{-1}$, respectively. The calculated values for this sample of two-stage VFCW plants are similar to those obtained by Mercoiret et al. (2010) (COD: mean $=646 \mathrm{mg}^{-\mathrm{L}^{-1}}$, SD = 395mg. $\mathrm{L}^{-1}$; BOD 5 : mean $=265 \mathrm{mg} \cdot \mathrm{L}^{-1}, \mathrm{SD}=171 \mathrm{mg} . \mathrm{L}^{-1}$; $\mathrm{TSS}:$ mean $=288 \mathrm{mg} \cdot \mathrm{L}^{-1}$, SD $=226 \mathrm{mg} . \mathrm{L}^{-1}$; TKN: mean $=67 \mathrm{mg} \cdot \mathrm{L}^{-1}, \mathrm{SD}=35 \mathrm{mg} \cdot \mathrm{L}^{-1}$ ).

\section{The two-stage VFCW}

Among all the plants identified in the database, the two-stage VFCWs represent 380 plants. Moreover, 422 composite samples are available from 119 different two-stage plants. Generally, the plants feature hydraulic and organic loads of about $94 \%$ and 54\%, respectively, with large variations on the first stage in operation (hydraulic load: mean: $0.37 \mathrm{~m} . \mathrm{d}^{-1}$; SD: $0.39 \mathrm{~m} . \mathrm{d}^{-1}$; min-max: $0.05-2.20 \mathrm{~m} \cdot \mathrm{d}^{-1}$ - organic load: mean: $161 \mathrm{mgCOD} \cdot \mathrm{m}^{-2} \cdot \mathrm{d}^{-1}$; SD: $104 \mathrm{mgCOD} \cdot \mathrm{m}^{-2} \cdot \mathrm{d}^{-1}$; min-max: $\left.12-557 \mathrm{mgCOD} \cdot \mathrm{m}^{-2} \cdot \mathrm{d}^{-1}\right)$.

Figure 3 presents the cumulative percentages for the COD, $\mathrm{BOD}_{5}$, TSS and TKN concentrations measured in the wastewater, the first-stage outlet and the second-stage outlet. 

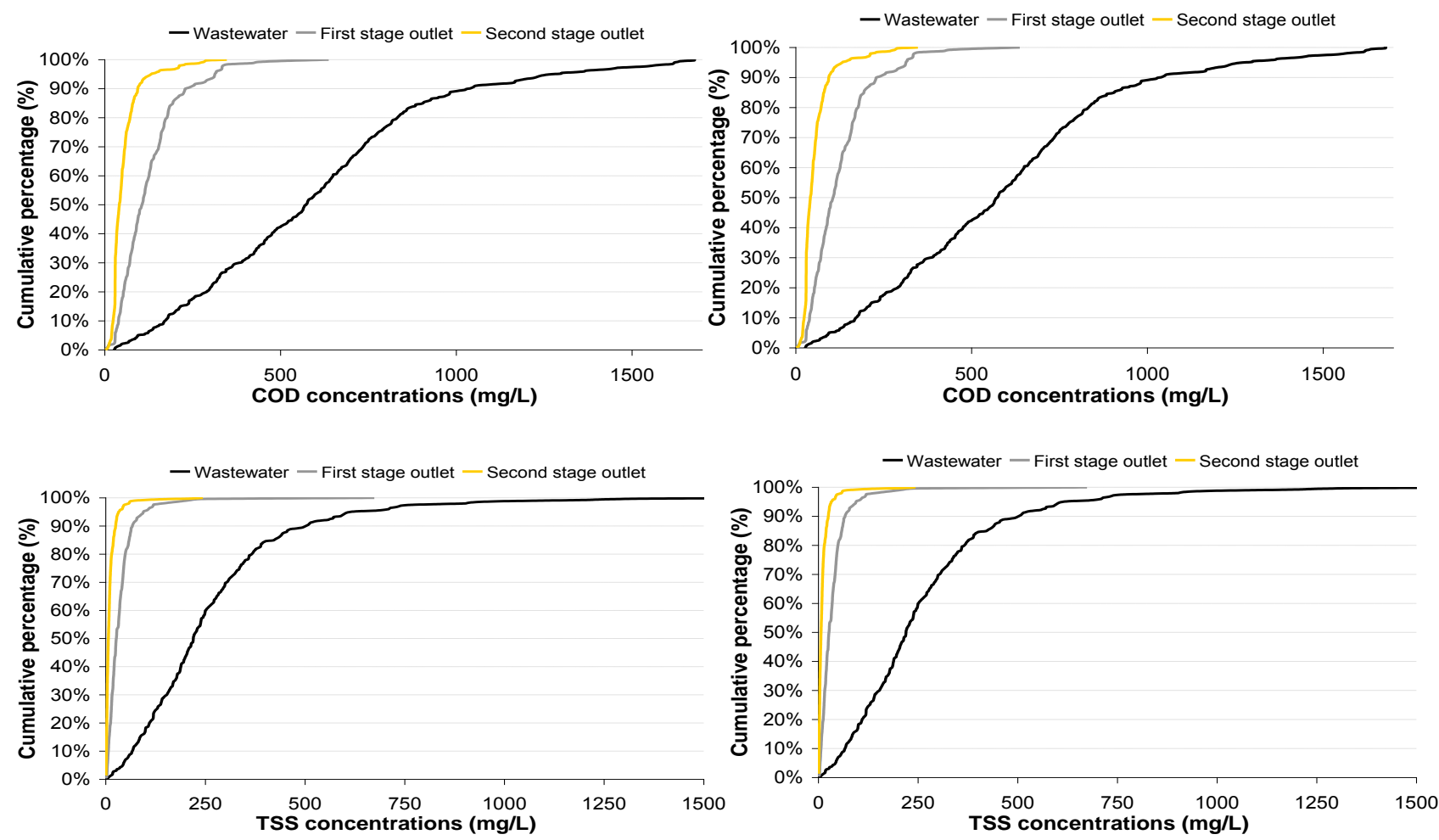

Figure 3. $\mathrm{COD}$ (top left), $\mathrm{BOD}_{5}$ (top right), TSS (bottom left) and TKN (bottom right) concentrations for the wastewater $\left(\mathrm{N}=394, \mathrm{~N}=386, \mathrm{~N}=397, \mathrm{~N}=325\right.$ for COD, $\mathrm{BOD}_{5}, \mathrm{TSS}$ and TKN, respectively), the first stage outlet $\left(\mathrm{N}=250, \mathrm{~N}=243, \mathrm{~N}=252, \mathrm{~N}=228\right.$ for COD, $\mathrm{BOD}_{5}$, TSS and TKN, respectively) and the second stage outlet $(\mathrm{N}=395, \mathrm{~N}=388, \mathrm{~N}=397, \mathrm{~N}=344$ for COD, $\mathrm{BOD}_{5}$, TSS and TKN, respectively)

While the wastewater concentrations are spread over a wide range of values, the concentration distributions at the second stage outlet are much denser and concentrations are low. This densification of the outlet concentrations is less apparent for TKN with a greater spread of values (min-max: 1-93mg.L $\mathrm{L}^{-1}$ ). For the four parameters represented in Figure 3 the $90 \%$ of COD, BOD TSS and TKN concentrations are below 95mg.L $\mathrm{L}^{-1}, 22 \mathrm{mg} . \mathrm{L}^{-1}, 25 \mathrm{mg} . \mathrm{L}^{-1}$ and 26mg. $\mathrm{L}^{-1}$, respectively.

Table 2. Effluent pollutant concentrations and removal efficiencies of the two-stage VFCW system

\begin{tabular}{|c|c|c|c|c|c|c|}
\hline & \multicolumn{2}{|c|}{$\mathrm{COD}$} & \multicolumn{2}{|c|}{ TSS } & \multicolumn{2}{|c|}{ TKN } \\
\hline & $\begin{array}{c}\text { Outlet } \\
\text { concentration } \\
\left(\mathrm{mg} \cdot \mathrm{L}^{-1}\right)\end{array}$ & $\begin{array}{l}\text { Removal } \\
\text { efficiency } \\
(\%)\end{array}$ & $\begin{array}{c}\text { Outlet } \\
\text { concentration } \\
\left(\mathrm{mg}^{-1} \mathrm{~L}^{-1}\right)\end{array}$ & $\begin{array}{c}\text { Removal } \\
\text { efficiency } \\
(\%)\end{array}$ & $\begin{array}{c}\text { Outlet } \\
\text { concentration } \\
\left(\mathrm{mg} . \mathrm{L}^{-1}\right)\end{array}$ & $\begin{array}{c}\text { Removal } \\
\text { efficiency } \\
(\%) \\
\end{array}$ \\
\hline $\begin{array}{c}\text { Mean } \pm X(N) \\
S D\end{array}$ & $\begin{array}{c}74 \pm 16(417) \\
168\end{array}$ & $\begin{array}{c}87 \pm 2(409) \\
14\end{array}$ & $\begin{array}{c}17 \pm 6(418) \\
64\end{array}$ & $\begin{array}{c}93 \pm 1(411) \\
9\end{array}$ & $\begin{array}{c}11 \pm 2(357) \\
13\end{array}$ & $\begin{array}{c}84 \pm 2(329) \\
17\end{array}$ \\
\hline $\begin{array}{l}\text { Molle et al. } \\
\quad(2005)\end{array}$ & $\begin{array}{c}66 \pm 13(49) \\
46\end{array}$ & $\begin{array}{c}91 \pm 3(49) \\
46\end{array}$ & $\begin{array}{c}14 \pm 5(49) \\
18\end{array}$ & $\begin{array}{c}95 \pm 2(49) \\
18\end{array}$ & $\begin{array}{c}13 \pm 5(49) \\
18\end{array}$ & $\begin{array}{c}85 \pm 5(49) \\
17\end{array}$ \\
\hline
\end{tabular}

SD: standard deviation; $\mathrm{N}$ : the number of values; $\pm \mathrm{X}=1.96 *(\mathrm{SD} / \sqrt{\mathrm{N}}): 95 \%$ confidence interval

Table 2 presents the average outlet concentrations and removal efficiencies for COD, TSS and TKN calculated for the global system. Removal efficiencies are $87 \%, 93 \%$ and $84 \%$ for COD, TSS and TKN, respectively. These values are consistent with those calculated by Molle et al. (2005) (91\%, $95 \%$ and $85 \%$ for COD, TSS and TKN, respectively) even if the plants are older in average (55\% of the plants are between 7 to 11 years old whereas most of the plants were 4 to 6 years old in Molle et 
$a l ., 2005)$ and the number of values is larger. The scatter of the outlet concentrations is greater than for the removal efficiencies even if the classic outlet requirements are respected $\left(125 \mathrm{mgCOD} . \mathrm{L}^{-1}\right.$, $35 \mathrm{mgTSS} . \mathrm{L}^{-1}$ and $25 \mathrm{mg} \mathrm{BOD} 5 . \mathrm{L}^{-1}$ ) even for pollutant loads up to 2 to 5 times the nominal load. These concentrations depend on characteristics in relation to the design (filter surface, height of the filter material) and operating (hydraulic loads). Therefore, the classical French system is still an efficient and robust method for treating wastewater from small communities.

Nevertheless, the overall efficiencies do not fully reflect the efficiency of each stage. Indeed, if one of the two stages fails to treat the pollutants, the other can compensate this dysfunction and smooth the removal efficiencies. It is often the first stage which faces some difficulties for treating TKN and the second stage which compensates the low TKN removal efficiencies. That is why we focus on the treatment effectiveness of the first stage.

\section{Focus on the first stage of VFCW}

Among all the plants identified in the database, the data including measurement at the outlet of the first stage concern 51 plants for a total of 252 composite samples.

As for the second stage, the concentration distributions at the first stage outlet (see Figure 3) are also denser compared to the wastewater concentration distributions for COD, BOD 5 , TSS and TKN (but less dense than the distributions of the second stage). As well, TKN concentrations present a larger range of values, from $1 \mathrm{mg} . \mathrm{L}^{-1}$ to $105 \mathrm{mg} . \mathrm{L}^{-1}$, than COD, BOD 5 and TSS. $90 \%$ of COD, $\mathrm{BOD}_{5}$, TSS and TKN concentrations are below 230mg.L $\mathrm{L}^{-1}, 80 \mathrm{mg} . \mathrm{L}^{-1}, 67 \mathrm{mg} . \mathrm{L}^{-1}$ and $55 \mathrm{mg} . \mathrm{L}^{-1}$, respectively.

Table 3. Effluent pollutant concentrations of the first stage of VFCW

\begin{tabular}{|c|c|c|c|c|c|c|}
\hline & \multicolumn{2}{|c|}{ COD } & \multicolumn{2}{|c|}{ TSS } & \multicolumn{2}{|c|}{ TKN } \\
\hline & $\begin{array}{c}\text { Outlet } \\
\text { concentration } \\
(\mathrm{mg} / \mathrm{L})\end{array}$ & $\begin{array}{c}\text { Removal } \\
\text { efficiency } \\
(\%) \\
\end{array}$ & $\begin{array}{c}\text { Outlet } \\
\text { concentration } \\
(\mathrm{mg} / \mathrm{L})\end{array}$ & $\begin{array}{c}\text { Removal } \\
\text { efficiency } \\
(\%)\end{array}$ & $\begin{array}{c}\text { Outlet } \\
\text { concentration } \\
(\mathrm{mg} / \mathrm{L})\end{array}$ & $\begin{array}{l}\text { Removal } \\
\text { efficiency } \\
(\%)\end{array}$ \\
\hline Mean $\pm X(N)$ & $126 \pm 11(250)$ & $77 \pm 2(250)$ & $38 \pm 4(252)$ & $83 \pm 2(252)$ & $27 \pm 2(228)$ & $59 \pm 3(223)$ \\
\hline SD & 90 & 14 & 33 & 15 & 19 & 21 \\
\hline $\begin{array}{l}\text { Molle et al. } \\
\quad \text { (2005) }\end{array}$ & $\begin{array}{c}131 \pm 20(54) \\
71\end{array}$ & $\begin{array}{c}79 \pm 3(54) \\
10\end{array}$ & $\begin{array}{c}33 \pm 6(54) \\
19\end{array}$ & $\begin{array}{c}86 \pm 3(54) \\
19\end{array}$ & $\begin{array}{c}31 \pm 5(54) \\
17\end{array}$ & $\begin{array}{c}58 \pm 5(54) \\
17\end{array}$ \\
\hline
\end{tabular}

Table 3 presents the average outlet concentrations and removal efficiencies for COD, TSS and TKN calculated for the first stage of treatment. These values confirm that the main roles of this treatment stage are the TSS retention (removal efficiency of 83\%) as well as the degradation of a part of the COD (removal efficiency of 77\%), as found in Molle et al. (2005). The stability of COD and TSS removal efficiencies is clear in Figure 4 (left). Figure 4 displays the removal efficiencies for COD, TSS and TKN relating to their respective loads applied on the first stage (the dashed line represents $100 \%$ removal). Despite the high loads applied on the first stage (until 2 times and 6 times the nominal load for COD and TSS respectively), the removal efficiencies for COD and TSS are satisfactory with removal efficiencies greater than $80 \%$ and $91 \%$, respectively. It highlights the robustness of the system i.e. how it can accept punctual overloads without affecting the removal rates. 

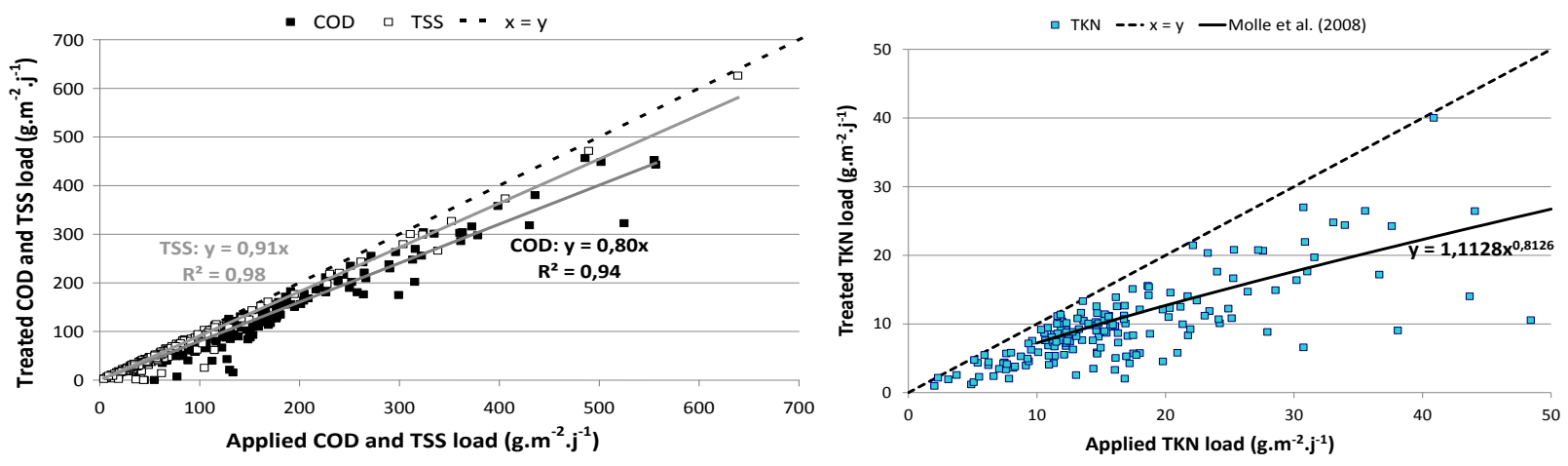

Figure 4. Treated COD, TSS (left) and TKN (right) loads according to the applied COD, TSS and TKN loads on the first stage of VFCW system. N=190 for COD and TSS loads; $\mathrm{N}=174$ for TKN loads

For this treatment stage, the TKN removal efficiency is less important $(60 \%, 58 \%$ in Molle et al. (2005)) than the COD and TSS ones. As expected, treatment performances decrease while the load increases. This has already been observed by previous studies (Molle et al., 2005; Molle et al., 2008) and reflects the limits the filter can reach in terms of oxygen renewal, hydraulic shortcuts and ammonium adsorption.

Nevertheless, Figure 4 (right) shows a wide dispersion of the values even for loads under the designed load (25-30gTKN.m-2 $\left.\cdot \mathrm{d}^{-1}\right)$. The fitting curve from Molle et al. (2008) (Figure 4, left) was obtained with a filter of $80 \mathrm{~cm}$ made of gravel with an intermediate aeration and a good distribution of the effluent on the filter. It can be considered as a reference curve since no dispersion on nitrification rate was measured whatever the season and the temperature. In comparison with TKN loads from Molle et al. (2008), values of this study are widely scattered around the curve. This highlights the greater sensitivity of the nitrification process to design and operating conditions. Many parameters can impact the nitrification rate such as design parameters (depth of material, particle size of the media, batch feeding system, including distribution pipes, and drainage pipes), as well as external factors (age of the filter, temperature, hydraulic load (storm event, clear water intrusion)), and operating parameters (alternation of filters, day of feeding) (Taniguchi et al., 2009; Stefanakis and Tsihrintzis, 2012). This graphical representation is not sufficient for involving one or more specific design and/or operation characteristics for explaining the dispersions observed around the general trend exposed in Figure 4 (right). They certainly result from one or the combination of several parameters.

This database currently lacks precise design information considering the depth and the particle size of the filtering media, as well as in term of maintenance quality. Thus it has not been possible to point out the main parameters that impact the nitrification process. Neither the hydraulic load alone, nor the age of the filter (Figure 5) explain this dispersion. Whatever the age of the plants at which the $24 \mathrm{~h}$-flow proportional composite samples is carried out, the treated TKN load is satisfactory. This does not mean that nitrification varies in unpredictable ways, but that the database needs to be more informed on design parameters. Indeed, when Molle et al. (2008) worked on one single filter, they measured no dispersion on nitrification rate whatever the season and the temperature. This stability might be linked to the depth of the filters used $(60 \mathrm{~cm}$ and $80 \mathrm{~cm}$ of filtration layer) and the particle size of $2-4 \mathrm{~mm}$. Indeed it is in accordance with the actual trend to modify the French guidelines to narrow the particle size distribution from $4-8 \mathrm{~mm}$ to $2-6 \mathrm{~mm}$ and even $2-4 \mathrm{~mm}$. As well, when nitrification requirements are stringent, using $60 \mathrm{~cm}$ of gravel is recommended for a single VFCW plant. 


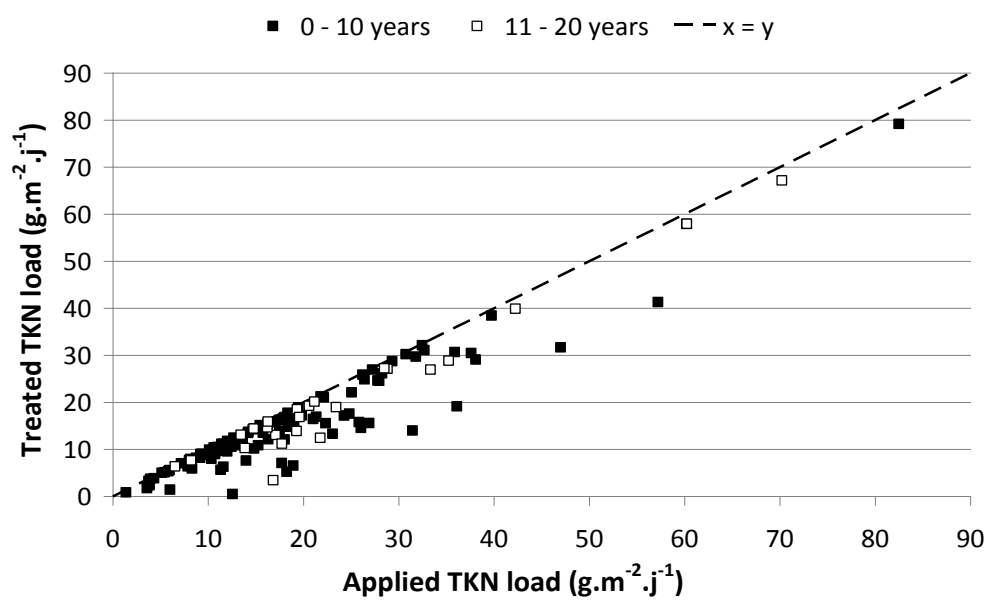

Figure 5. Treated TKN loads according to the applied TKN loads on the first stage of old VFCW plants (aged from 13 to 20 years) according to the age of the plants when the composite samples were made. $\mathrm{N}=131$

\section{CONCLUSION}

This study reviewed the performance of the two-stage VFCW in series and of the first stage of VFCWs alone, all of them fed with raw wastewater. It was highlighted and confirmed that the twostage configuration is robust and suitable for the treatment of raw sewage. Moreover, we state that:

- Performances observed in this study are consistent with previous data set. Over a wide range of plants aged from 2 to 31 years (mean of 10 years), concentrations measured at the outlet of the second stage and removal efficiencies are substantially close to the previous study conducted 10 years earlier on the same configuration: $74 \mathrm{mgCOD} . \mathrm{L}^{-1}$ (COD removal efficiency of $87 \%$ ), $17 \mathrm{mgTSS}^{-1}$ (TSS removal efficiency of $93 \%$ ) and $11 \mathrm{mgTKN}^{-1}$ (TKN $^{-1}$ removal efficiency of $84 \%$ ).

- Robust performances for TSS and COD for the $1^{\text {st }}$ stage. Values confirm that the main roles of the first treatment stage are TSS retention (removal efficiency of 83\%) as well as degradation of a part of the COD (removal efficiency of 77\%).

- Good but variable performance for TKN for the $1^{\text {st }}$ stage. There is a large dispersion of the treated TKN load values according to the TKN load applied. Due to the lack of information related to the design parameters or operating conditions of the plants, no characteristics have been highlighted for demonstrating the effects on the nitrification process.

A statistical study is currently underway with the aim to explain the variations in TKN removal efficiencies observed on the first stage. This effort entails filling in the missing data in the database and resampling values to avoid bias and to better decompose the variance.

\section{REFERENCES}

Aguilera Soriano, G., Raveneau-Champion, B., Dauthuille, P. (2011). The Rhizopur® process ten years on: A green solution for sewage treatment in small communities. Wat. Sci. Tech.63(8):16141620.

APHA (American Public Health Association) (2012). In: Rice, E.W., Baird, R.B., Eaton, A.D., Clesceri, L.S. (Eds.),AWWA/APHA/WEF Standard Methods for the Examination of Water and Wastewater, 22nd ed, 1496 pp. 
Kim, B., Gautier, M., Prost-Boucle, S., Molle, P., Michel, P., Gourdon, R. (2014). Performance evaluation of partially saturated vertical-flow constructed wetland with trickling filter and chemical precipitation for domestic and winery wastewaters treatment. Ecol. Eng.71:41-47.

Liénard, A., Boutin, C. and Esser, D. (1990a). Domestic wastewater treatment with emergent hydrophyte beds in France. In: Constructed Wetlands in Water Pollution Control (Adv. Wat. Pollut. Control no 11), Cooper, P.F. and Findlater, B.C. (eds), Pergamon Press, United Kingdom, pp. 183192.

Liénard, A., Esser, D., Deguin, A. and Virloget, F. (1990b). Sludge dewatering and drying in reed beds: an interesting solution? General investigation and first trials in France. In: Constructed Wetlands in Water Pollution Control (Adv. Wat. Pollut. Control no 11), Cooper, P.F. and Findlater, B.C. (eds). Pergamon Press, United Kingdom, pp. 257-267.

Mercoiret, L., Molle, P. and Forquet, N. (2010). Domestic wastewater characteristics in French rural areas: concentrations and ratios for treatment plant under 2000 population equivalent (120 $\mathrm{kg}$ of $\mathrm{BOD}_{5}$ a day). 3rd International Smallwat Congress, Seville, Spain.

Molle, P., A. Liénard, C. Boutin, G. Merlin, and Iwema, A. (2005). How to treat raw sewage with constructed wetlands: an overview of the French systems. Wat. Sci. Tech. 51(9):11-21.

Molle, P., Prost-Boucle, S. and Liénard, A. (2008).Potential for total nitrogen removal by combining vertical flow and horizontal flow constructed wetlands: A full-scale experiment study. Ecol. Eng.34:23-29.

Prost-Boucle, S. and Molle, P. (2012). Recirculation on a single stage of vertical flow constructed wetland: Treatment limits and operation modes. Ecol. Eng.43:81-84.

Stefanakis, A.I. and Tsihrintzis,V.A. (2012). Effects of loading, resting period, temperature, porous media, vegetation and aeration on performance of pilot-scale vertical flow constructed wetlands. Chem. Eng. J.181-182:416- 430.

Taniguchi, T., Nakano,K., Chiba, N., Nomura, M. and Nishimura, O. (2009). Evaluation of extremely shallow vertical subsurface flow constructed wetland for nutrient removal. Wat. Sci. Tech.59(2):295-301. 